\title{
Review of Hosein Aabad Sugar Factory (HASF) Wastewater and Assessment of its Pollution Load
}

\section{${ }^{* 1}$ MAHDI REYAHI KHORAM; ${ }^{2}$ MAHDI SAFIKHANI; ${ }^{2}$ SEYED MOSTAFA KHEZRI}

\author{
${ }^{1}$ Department of Environment, Islamic Azad University- Hamadan Branch, Imam Khomeini Blvd. Professor \\ Musivand Blvd. Hamadan, Iran. \\ ${ }^{2}$ Department of Environmental Engineering, Science and Research Branch, Islamic Azad University, Hesarak, \\ Poonak, Tehran, Iran
}

KEYWORDS: Sugar industry, pollution load, emission factor, wastewater

\begin{abstract}
Sugar industry is one of the largest industries in the world. Hosein Abad sugar factory (HASF) is located in Hamadan province of Iran. The aim of this research was to evaluate the quality and quantity of wastewater of the said factory and to estimate the pollution load and its emission factor as prerequisite of the management and environmental pollutions control in the region. Random grab sampling is used in twelve days between October 2010 and March 2011 during peak hours of activity. In this research, nine quality parameters as the key variables are measured to evaluate the quality of wastewater. The obtained results indicate that, the amount of wastewater produced by HASF is about 2740 $\mathrm{m}^{3} /$ day. Based on the said results, the average amount of five days Biochemical Oxygen Demand $\left(\mathrm{BOD}_{5}\right)$ and Chemical Oxygen Demand $(\mathrm{COD})$ in the raw wastewater was 1296 and $2328 \mathrm{mg} / \mathrm{l}$ respectively. The results of this research showed that the effluent wastewater of HASF in the present conditions is highly polluted due to inappropriate treating and is not appropriate for artificial recharge use, discharge in rivers and lakes or utilization in agriculture, according to the DoE standards. @ JASEM
\end{abstract}

http://dx.doi.org/10.4314/jasem.v17i3.8

*Corresponding author E mail: phdmrk@gmail.com 
Food processing is one of the most high-water-use industries and the amount of its wastewater is relatively high and dependent on the process details (Reyahi khoram et al., 2009). Food processing industries are those whose main concern is the production of edible goods for human or animal consumption (Nemerow and Agardy, 1998). The increases in sensitivity and demand of the general public for a clean and pleasant environment have forced all of these industries to control air and water pollution (Rappert and Müller, 2005). Food processing wastewaters typically contain high concentrations of biodegradable organic matter (Nelson and Sidhu, 2007). Mentioned industries are divided into two seasonal and non-seasonal industries. In seasonal industries, the process of production is made in special months of the year (Mosafery, 2003). Sugar industry is one of the largest industries in the world. Today, sugarcane is produced in over 110 countries (Awasthi et al., 2011).

Hosein Abad sugar factory (HASF) is located in Hamadan province of Iran, covering 46 hectares and next to Hosein Abad village. HASF is a seasonal industry, operating during the fall and winter seasons lasting about 6 months in a year. HASF is one of the oldest industries in the province with three working shifts a day and many of its facilities are worn out. The nominal capacity of the plant is approximately 2000 tones of sugar beet and production of 260 tones sugar per day. Regarding Exhaustion Issues of the factory installations, its capacity is reduced to about $52 \%$ of the designed capacity. This factory has approximately 700 employees as permanent workers and temporary workers and workers' normal shift is eight hour a day, seven days a week.

Environmental problems in the traditional beet sugar processing are mainly related to the production of large consumption of energy and water (Vaccaria et al., 2005). Regarding the importance of environment as a public issue, it is necessary to assessing and monitoring the environmental pollutions such as industrial waste waters. On this basis, the purpose of the present study was to evaluate the quality and quantity of wastewater of the said factory, estimate the pollution load and its emission factor as the prerequisite of the management and environmental pollutions control in the region.

\section{MATERIALS AND METHODS}

This research survey was carried out during 2009 to 2011. First, general status of HASF was studied by conducting library studying and field visits and on its basis, necessary planning was made to determine quality, quantity and amount of pollution away from it. Based on the water consumption, production level and the number of workers, the amount of industrial wastewater and municipal wastewater of the factory was determined. Regarding the seasonal nature of the factory operations, wastewater sampling was performed in two seasons of fall and winter. A computer random number generator was used to choose the sampling days and sample size for six mounts was 12 . Therefore, random grab sampling is used in 12 days between October 2010 and March 2011 during peak hours of activity.

In this research, nine quality parameters including Dissolved Oxygen (DO), Chemical Oxygen Demand (COD), five days Biochemical Oxygen Demand $\left(\mathrm{BOD}_{5}\right)$, Electrical Conductivity (EC), Total Coliform (TC), Fecal Coliform (FC), Total Dissolved Solid (TDS), Total Suspended Solid (TSS) and PH as the key variables are measured to evaluate the quality of wastewater. Sample collection and measurement of wastewater quality parameters followed procedures outlined in Standard Methods (APHA, 2005). Wastewater grab samples were kept in the dark at $4^{\circ} \mathrm{C}$ until analyzed or further processed and preserved. All analyses were run within the allowed holding time applicable to the preservation method used. In this research, the cluster analysis method was used to isolate the groups of variables and in this relation, MultiVariate Statistical Package (MVSP) software were used (Darvish Kojouri, 2009).

\section{RESULTS AND DISCUSSION}

There are no permanent surface water sources in the studied area and the water required for mentioned industry is supplied from seven wells. In the operating license issued for the factory, all water that has been authorized for use or consumption not to exceed 957360 cubic meters per year. Regarding the old age of HASF installations, the amount of water consumed in the factory was more than authorized and during the past years, by applying some executive and experimental projects, it was attempted to reduce the amount of water consumption in HASF and reduce it by authorized amount of 957360 cubic meters per year. A high percentage of supplied water is actually used in the power plant of factory and also in the process of steam production. The obtained results indicate that, the amount of wastewater produced by HASF is about 2740 cubic meters per day. About 3 to 4 percent of this amount is related to municipal or human wastewater of the factory

Table 1 shows the major wastewater quality parameters of HASF. Based on the said results, the average amount of $\mathrm{BOD}_{5}$ and $\mathrm{COD}$ in the raw wastewater was 1296 and $2328 \mathrm{mg} / \mathrm{l}$, respectively. In HASF, the efficiency of wastewater treatment is

\section{${ }^{1}$ MAHDI REYAHI KHORAM; ${ }^{2}$ MAHDI SAFIKHANI; ${ }^{2}$ SEYED MOSTAFA KHEZRI}


highly defective and it's really a very painful, undesirable performance and does not view supervision as assistance, sharing and helping to solve the problems. In this situation, if the wastewater of HASF enters the environment, without any appreciable treatment, the amount of pollution load, in wastewater that can be discharged into the environment, is estimated to amount to 640 tons per year (based on $\mathrm{BOD}_{5}$ values). Thus, HASF that processes 2000 tones of sugar beet per day consumes approximately $5320 \mathrm{~m}^{3}$, which is equivalent to the daily consumption of a population of nearly 30000 inhabitants with an average consumption of 180 liters of water/inhabitant per day and is equivalent to the pollution load of a population of nearly 70000 people.

In the best conditions possible, wastewater treatment efficiency in HASF may be obtained in about 30 percent and in this situation, the amount of pollution load of the wastewater will be estimated to amount to 448 tons per year (based on $\mathrm{BOD}_{5}$ values) and is equivalent to the pollution load of a population of nearly 50000 people. The amount of pollution load of the wastewater of HASF based on COD and TSS is mentioned in table 2 .

\begin{tabular}{|c|c|c|c|}
\hline Variable & $(95 \%$ CI) $\bar{X}$ & Std.D & Std.E \\
\hline $\mathrm{BOD}_{5}(\mathrm{mg} / \mathrm{l})$ & $1296.25(1023.05,1569.45)$ & 429.993 & 124.128 \\
\hline $\mathrm{COD}(\mathrm{mg} / \mathrm{l})$ & $2327.83(1816.96,2838.70)$ & 804.053 & 232.110 \\
\hline $\mathrm{TSS}(\mathrm{mg} / \mathrm{l})$ & 703.83(490.30,917.37) & 336.082 & 97.018 \\
\hline TDS(mg/l) & $2037.92(1274.12,2801.71)$ & 1202.128 & 347.024 \\
\hline PH & $7.150(6.699,7.601)$ & 0.7103 & 0.2050 \\
\hline $\mathrm{EC}(\mu \mathrm{S} / \mathrm{cm})$ & $1956.58(1489.81,2423.36)$ & 734.655 & 212.077 \\
\hline $\mathrm{DO}(\mathrm{mg} / \mathrm{l})$ & $1.126(0.985,1.267)$ & 0.2216 & 0.0640 \\
\hline $\mathrm{TC}(\mathrm{No} / 100 \mathrm{cc})$ & $1286.17(927.22,1645.11)$ & 564.941 & 163.085 \\
\hline $\mathrm{FC}(\mathrm{No} / 100 \mathrm{cc})$ & $1364.42(872.08,1856.75)$ & 774.883 & 223.689 \\
\hline
\end{tabular}

Table 2. Summary of pollution load related to effluents of HASF

\begin{tabular}{lcccr}
\hline Factor & $(\mathrm{mg} / \mathrm{lit})$ & $\begin{array}{c}\text { Effluent } \\
\left(\mathrm{m}^{3} / \mathrm{day}\right)\end{array}$ & $\begin{array}{c}\text { Effluent } \\
\left(\mathrm{m}^{3} / \text { year }\right)\end{array}$ & $\begin{array}{r}\text { Pollution load } \\
\text { (tons/year) }\end{array}$ \\
\hline BOD $_{5}$ & 1296 & 2740 & 493200 & 639 \\
$\mathrm{COD}$ & 2328 & 2740 & 493200 & 1148 \\
$\mathrm{TSS}$ & 704 & 2740 & 493200 & 347 \\
\hline
\end{tabular}

Regarding that HASF typically operate 180 days per year, the amount of sugar production will be estimated as 46800 tons per year. On this basis the pollution emission factor of the wastewater (based on $\mathrm{BOD}_{5}$ values) is equivalent to $13.6 \mathrm{Kg}$ pollution for each ton of manufactured product. The pollution emission factor of the wastewater regarding COD and TSS is mentioned in table 3 . Whereas the amount of annual water consumed in the factory is equivalent to 957360 cubic meters, pollution emission factor of its wastewater (based on $\mathrm{BOD}_{5}$ values) is equivalent to $0.67 \mathrm{Kg}$ pollution for each cubic meter of water consumed per year. The pollution emission factor of this factory based on COD and TSS of wastewater is shown in table 3 . The results of cluster analysis are presented in a dendrogram (Fig. 1).

There are several studies, which estimated the quality parameters as $\mathrm{BOD}_{5}$, COD and TDS of effluent from various sugar industries in countries around the world (Akali et al., 2011; Singh and Kumar, 2010; Doke et al., 2011; Yuan-An and Yuan-jin, 2004). Recent studies conducted in India indicate that the EC, COD and TDS of effluent from a sugar industry located at Bhavninagar, Indapur and Pune was achieved 3400, 1330 and $720 \mathrm{mg} / \mathrm{l}$, respectively (Doke et al., 2011). Also Yuan-an and Yuan-jin (2004) reported that the characteristics of the combined wastewater from Guangxi sugar mills factory in china such as $\mathrm{BOD}_{5}$,

\section{${ }^{1}$ MAHDI REYAHI KHORAM; ${ }^{2}$ MAHDI SAFIKHANI; ${ }^{2}$ SEYED MOSTAFA KHEZRI}


COD and TSS was achieved 300-2000, 600-4300 and 400-2200 mg/l, respectively.

This research showed that wastewater treatment plant of HASF is not in a satisfactory condition and during past years, it has been repeatedly reviewed, corrected and completed. During implementation of this research, wastewater is treated defectively and with small efficiency and then it was discharged to a local waterway surrounding the factory. Regarding limitation of water resources, the said wastewater was used by farmers of the region during spring and summer for irrigation of agricultural products, and in other seasons of the year it is naturally absorbed into the underground water table.

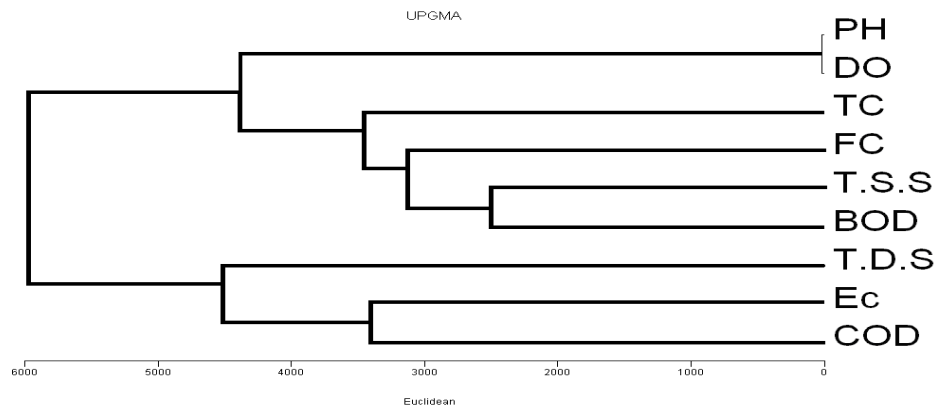

Fig 1. Dendrogram resulting from clustering with nine quality parameters obtained from wastewater analyses

\begin{tabular}{|c|c|c|c|}
\hline based on: & Factor & $\begin{array}{l}\text { Pollution } \\
\text { load } \\
\text { (tonnes } \\
\text { /year) }\end{array}$ & $\begin{array}{r}\text { Emission } \\
\text { Factor } \\
(\mathrm{Kg} / \\
\text { tonnes/year) }\end{array}$ \\
\hline finished & $\mathrm{BOD}_{5}$ & 639 & 13.6 \\
\hline product & COD & 1148 & 24.4 \\
\hline $\begin{array}{r}47000 \\
\text { (tones/year) }\end{array}$ & TSS & 347 & 7.4 \\
\hline water & $\mathrm{BOD}_{5}$ & 639 & 0.67 \\
\hline consumption & COD & 1148 & 1.2 \\
\hline $\begin{array}{l}957360 \\
\text { (tones/year) }\end{array}$ & TSS & 347 & 0.36 \\
\hline
\end{tabular}

As wastewater discharge is one of the major concerns of governments, organizations active in the environment filed and neighborhood communities, Iranian Department of Environment (DoE), has issued the effluent standards in three categories; Irrigation, artificial recharge of groundwater and discharge to rivers and lakes. The results of t-test analysis with 95 percent confidence level showed that the amount of $\mathrm{BOD}_{5}$ and $\mathrm{COD}$ of effluent wastewater of this factory is not equal to the standards of DoE for artificial recharge use, discharge in rivers and lakes or utilization in agriculture. Other analyses and comparisons to standards of DoE are shown in tables 4.

Thus, the effluent wastewater of HASF in the present conditions is highly polluted and is not appropriate for artificial recharge use, discharge in rivers and lakes or utilization in agriculture, according to the DoE standards. Sajani and Muthukkaruppan (2011) reported that, physicochemical Parameters such as $\mathrm{pH}$, electrical conductivity, COD, chloride, hardness, calcium, magnesium, sulphate and TDS were relatively high in the sugar factory effluent and severely affected paddy seed germination. There was a gradual decrease in the percentage seed germination

and germination value with sugar industry effluent concentration. The untreated sugar industry effluent could possibly lead to soil deterioration and low productivity. Terrestrial and aquatic environmental pollution could be averted by proper treatment of the effluents using suitable conventional methods.

According to dendrogram (Fig. 1), the parameters of COD, EC, and TDS are placed in one cluster. Therefore, it can be concluded that a part of TDS content in the wastewater is due to high TDS of the

\section{${ }^{1}$ MAHDI REYAHI KHORAM; ${ }^{2}$ MAHDI SAFIKHANI; ${ }^{2}$ SEYED MOSTAFA KHEZRI}


water consumed in the factory or due to transfer of the soil adhering to sugar beet. Based on the scientific documents and the studies, there is a positive linear relationship between EC and TDS; and this relationship is observed in the dendrogram as well.

Also, the results showed that there is a meaningful relationship between $\mathrm{PH}, \mathrm{DO}, \mathrm{TC}, \mathrm{FC}, \mathrm{TSS}$, and $\mathrm{BOD}_{5}$ (Fig. 1). With regard to the said clusters of dendrogram, it is observed that $\mathrm{BOD}_{5}$ and TSS as these are the two indexes of municipal wastewater with TC and FC are placed in one cluster. The fact is that there is no meaningful relationship between COD and FC; because FC has municipal wastewater origin and COD has industrial wastewater origin. On the other side, there is meaningful relationship between TSS and $\mathrm{BOD}_{5}$; because, a part of $\mathrm{BOD}_{5}$ content in the wastewater is because of suspended solids and colloidal matter inside the wastewater. Because of defective utilization of treatment plant and not treating according to standard conditions, it is estimated that groundwater quality in the studied area will be affected by the factory effluent. Today, in Hosein Abad village the water is not drinkable and the villagers of the area use bottled water to drink. It is obvious that in case of continuation of failure, the drinking water of adjacent villages will suffer the problem of drinking water of Hosein Abad village in the future. These problems have a negative impact on migration from rural areas to urban areas and residence in shanty towns in the margins of cities such as Hamadan and serious societal abnormalities and outright crimes will fall.

Table 4. The results of t-test comparisons between HASF effluent and DoE standards

\begin{tabular}{|c|c|c|c|c|c|c|c|}
\hline Effluent use: & Factor & $\mathrm{n}$ & Mean & Std.D & Standard value & $\mathrm{t}$ & $\mathrm{P}$ value \\
\hline \multirow{5}{*}{$\begin{array}{l}\text { in } \\
\text { agriculture }\end{array}$} & $\mathrm{BOD}_{5}(\mathrm{mg} / \mathrm{l})$ & 12 & 1296.25 & 429.993 & 100 & 9.637 & $0.001^{*}$ \\
\hline & $\mathrm{COD}(\mathrm{mg} / \mathrm{l})$ & 12 & 2327.83 & 804.053 & 200 & 9.167 & $0.001^{*}$ \\
\hline & $\mathrm{TC}(\mathrm{No} / 100 \mathrm{cc})$ & 12 & 1286.17 & 564.941 & 1000 & 1.755 & $0.107^{*}$ \\
\hline & $\mathrm{FC}(\mathrm{No} / 100 \mathrm{cc})$ & 12 & 1364.42 & 774.883 & 400 & 4.311 & $0.001^{*}$ \\
\hline & $\mathrm{PH}$ & 12 & 7.150 & 0.7103 & $(6-8.5)$ & -0.488 & $0.635^{*}$ \\
\hline for & $\mathrm{BOD}_{5}(\mathrm{mg} / \mathrm{l})$ & 12 & 1296.25 & 429.993 & 30 & 10.201 & $0.001^{*}$ \\
\hline \multirow[t]{4}{*}{ artificial recharge } & $\mathrm{COD}(\mathrm{mg} / \mathrm{l})$ & 12 & 2327.83 & 804.053 & 60 & 9.771 & $0.001^{*}$ \\
\hline & $\mathrm{TC}(\mathrm{No} / 100 \mathrm{cc})$ & 12 & 1286.17 & 564.941 & 1000 & 1.755 & $0.107^{*}$ \\
\hline & $\mathrm{FC}(\mathrm{No} / 100 \mathrm{cc})$ & 12 & 1364.42 & 774.883 & 400 & 4.311 & $0.001^{*}$ \\
\hline & $\mathrm{PH}$ & 12 & 7.150 & 0.7103 & $(5-9)$ & 0.732 & $0.480^{*}$ \\
\hline for & $\mathrm{BOD}_{5}(\mathrm{mg} / \mathrm{l})$ & 12 & 1296.25 & 429.993 & 30 & 10.201 & $0.001^{*}$ \\
\hline discharge to & $\mathrm{COD}(\mathrm{mg} / \mathrm{l})$ & 12 & 2327.83 & 804.053 & 60 & 9.771 & $0.001^{*}$ \\
\hline surface waters as & $\mathrm{TC}(\mathrm{No} / 100 \mathrm{cc})$ & 12 & 1286.17 & 564.941 & 1000 & 1.755 & $0.107^{*}$ \\
\hline \multirow[t]{2}{*}{ rivers and lakes } & $\mathrm{FC}(\mathrm{No} / 100 \mathrm{cc})$ & 12 & 1364.42 & 774.883 & 400 & 4.311 & $0.001^{*}$ \\
\hline & $\mathrm{PH}$ & 12 & 7.150 & 0.7103 & $(6.5-8.5)$ & -1.707 & $0.116^{*}$ \\
\hline
\end{tabular}

"Significant; $p<0.05$

In this situation, it is necessary that managers of HASF complete the projects related to deployment of wastewater treatment plant at the earliest possible time and Hamadan Provincial Directorate of Environmental Protection should control and manage the pollutions of the factory as per regulations. Finally, the implementation of Environmental Management System (EMS) is recommended as the standard monitoring and evaluation framework to improve economic and environmental performance of sugar processing in HASF.

\section{REFERENCES}

Akali, N M; Nyongesa, N D; Neyole, E M; Miima, J B (2011). Effluent Discharge by Mumias Sugar Company in Kenya: An Empirical Investigation of the Pollution of River Nzoia. Sacha Journal of Environmental Studies, 1(1), 1-3.

American Public Health Association (APHA) (2005). Standard methods for Examination of water and Wastewater, $21^{\text {th }}$ Edition, APHA, Washington D C.

\section{${ }^{1}$ MAHDI REYAHI KHORAM; ${ }^{2}$ MAHDI SAFIKHANI; ${ }^{2}$ SEYED MOSTAFA KHEZRI}

Acknowledgements :This research was supported by Hamadan Provincial Directorate of Environmental Protection, to which the authors' thanks are due. The authors also thank Mr. Mohammad pour, the head of Hamadan Provincial Directorate of Environmental Protection, for their collaboration in this study. Also special thanks to Iraj Asadi, Mino Nafea, Fatemeh Zand, Fereshteh Gadery, Amir Mahdaviani and other experts for their participation.

Awasthi, A K; pandey, A K; Rashmi, D (2011). Diversity of fungi effluents of sugar industries of Madhya Pradesh, International Journal of Environmental sciences, 1(5), 834-838

Darvish Kojouri, F (2009). An introduction to applied multivariate statistical Methods, Science and Research Branch publisher of Islamic Azad University, Tehran. 
Doke, K M; Ejazuddin, M K; Joseph, R; Asif, S. (2011). physico-chemical analysis of sugar industry effluent and its effect on seed germination of vigna angularis, vigna cylindrical and sorghum cernum. Annals of Environmental Science, 5, 7-11.

Mosafery, M (2003). An introduction to management of food industries wastewater, Department of Environment (DoE), Tehran.

Nelson, M I; Sidhu, H S (2007). Reducing the emission of pollutants in food processing wastewaters, Chemical Engineering Process, 46(5), 429-436.

Nemerow, N L; Agardy F J (1998). Strategies of industrial and hazardous waste management, International Thomson publishing company, USA.

Rappert, S; Müller, R (2005). Odor compounds in waste gas emissions from agricultural operations and food industries. Waste Management, 25(9), 887-907.

Yuan-An, W; Yuan-jin, X (2004). Eco-friendly Management of Sugar Industry Effluents in Guangxi China. Sugar industry, 5(4), 285 - 290.
Reyahi khoram, M; Nafea, M; Hashemy, M (2009). Investigation on characteristic of currentfinishing wastes in Malayer township in Iran, The proceeding of $12^{\text {th }}$ national congress of environmental health, 2-3November 2009, Tehran.

Sajani, S and Muthukkaruppan, S M (2011). Physico -Chemical Analysis of Sugar Mill Effluent, Contaminated Soil and its Effect on Seed Germination of Paddy (Oryza sativa L.), International Journal of Pharmaceutical \& Biological Archives, 2(5), 1469-1472.

Singh, J P; Kumar, A (2010). Effect of sugar mill effluents on the physico -chemical nature of water of the river Kuwano at Waltergang, Basti, U.P. Journal of Experimental Zoology India, 13(2), 545-546.

Vaccaria, G; Tamburinia, E; Sgualdinoa, G; Urbaniecb, K; Klemešc, J (2005). Overview of the environmental problems in beet sugar processing: possible solutions. Journal of Cleaner Production, 13(5), 499-507. 